\title{
ARTICLE NINE OF JAPAN'S \\ CONSTITUTION: FROM \\ RENUNCIATION OF ARMED FORCE \\ "FOREVER" TO THE THIRD \\ LARGEST DEFENSE BUDGET \\ IN THE WORLD
}

\author{
James E. Auer*
}

\section{INTRODUCTION}

In 1928, the United States and France took the lead in an attempt to outlaw war as a means of settling disputes among nations. The KelloggBriand Pact was signed and ratified by all great powers of that time, including Japan. Despite the fact that the Pact, in theory, continues to be in effect-no nation has to this day revoked its approval-less than fifteen years after the Pact's adoption, World War II commenced.

Following the defeat of Japan and during the Occupation, the Supreme Commander of the Allied Powers ("SCAP"), General Douglas MacArthur, directed his staff to include in Japan's postwar Constitution a provision banning a Japanese army, navy, or air force for any purpose, including preserving Japanese security. MacArthur's directive was modified by his own staff, which transmitted a draft constitution to the Government of Japan ("GOJ") that further modified the wording, leaving some room for interpretation about the possibility of armed forces for defensive purposes. MacArthur himself adopted this position after the outbreak of the Korean War in 1950 and then claimed that he never intended that Japan not have the means for self-defense.

Nonetheless, the Japanese Government, when explaining the new Constitution to the public before it became effective in May 1947, stated that all armed force was outlawed for all purposes. The Constitution has not been amended thus far, yet SCAP ordered Japan to form a 75,000-man National Police Reserve in 1950, which became the National Safety Forces in 1952 and the Self-Defense Forces in 1954. Today the Self-Defense Forces' budget has become the third largest military budget in the world, following those of the

\footnotetext{
Copyright @ 1990 by Law and Contemporary Problems

* Director, Center for U.S.-Japan Studies and Cooperation, Vanderbilt Institute for Public Policy Studies, Vanderbilt University.
} 
United States and the USSR. Japan has pursued military development and simultaneously has attempted to live up to the ideals of the Constitution to a degree that the signers of the Kellogg-Briand Pact, including Japan, never did.

\section{II}

\section{BACKGROUND}

Even before Japan was demobilized following its surrender in August 1945 , there was movement to insure that Japan would never again pose a threat to its World War II enemies. The Kellogg-Briand Pact of 1928, which was signed and ratified by the United States, the Soviet Union, the United Kingdom, France, Germany, Japan, and many other nations, outlawed war; however, it obviously did not succeed in preventing the worst war the world had ever seen.' The American-dominated Occupation sought to try again to restrict Japan's ability to wage war. ${ }^{2}$

On October 4, 1945, General MacArthur told the GOJ, in the person of Prince Konoye, Minister of State without Portfolio in the Higashi Kuni Cabinet, that there was a need to reform the Constitution. MacArthur repeated the call to Prime Minister Shidehara on October 11, two days after the formation of Shidehara's new Cabinet. A committee of scholars under Matsumoto, another Minister without Portfolio, was formed to consider the necessity of revision.

Two proposals based upon the basic principles of the Meiji Constitution emerged from the committee: a relatively conservative "Draft A" prepared by Matsumoto personally and a more liberal "Draft B" prepared by the whole committee. The authors stated that the drafts were designed to prevent future abuses of the Constitution by amending some articles. ${ }^{3}$ With respect to

1. In ratifying the Kellogg-Briand Pact, the United States Senate added two conditions insisted upon by Senator Borah: (1) that any nation would be allowed to defend itself by force if attacked and (2) that each nation would decide for itself what constitutes self-defense. Some scholars view the second clause, in particular, as permitting all but self-declared wars of aggression, of which history records few, if any.

2. The most complete work on the new Japanese Constitution is the report of a Japanese government investigation commission that met from 1957 to 1964 and that returned a report of over 40,000 pages contained in almost 500 volumes, plus 100 volumes of reference material. CомM' $N$ ON the Constitution, Report on the Commission on the Constitution (1958-1964) (D. Maki trans. 1980) [hereinafter Commission]. The official account of the Supreme Commander of Allied Powers ("SCAP") is contained in Supreme Commander for the Allied Powers, Report of Government Section, The Political Reorientation of Japan, September 1945 to September 1948 (1949) [hereinafter Political Reorientation]. For other English sources concerning Article 9, see $\mathrm{O}$. Nishi, The Constitution and the National Defense law System in Japan (1987); Maki, The Documents of Japan's Commission on the Constitution, 24 J. Asian STud. 475 (1965); Sato, The Origin and Development of the Draft Constitution of Japan, 34 ConTEMP. JAPAN 175 (1956); Ward, The Commission on the Constitution and Prospects for Constitutional Change in Japan, 24 J. Asian Stud. 401 (1965). Sato was a member of the Cabinet Legislative Bureau during the drafting of the Constitution; Ward and Maki were American scholars working with the Constitution. See also The Constitution of JAPan: Its First TwENTY Years, 1947-1967 (D. Henderson, ed. 1968) [hereinafter First Twenty Years]; McNelly, The Renunciation of War in the Japanese Constitution, 77 PoL. ScI. Q. 350 (1962).

3. The Meiji Constitution established the imperial army and navy as Cabinet ministries. Subsequent legislation required that the army and navy ministers be active duty officers so that 
armed forces, Draft A stated: "The system of armed forces is retained. The supreme command of the armed forces may not be exercised independently, except with the advice of the Ministers of State."4 Draft B deleted the Meiji Constitution's references to armed forces but did not appear to prohibit the maintenance or use of such forces. ${ }^{5}$

The Shidehara Cabinet submitted Draft A to the General Headquarters ("GHQ") of SCAP in early February 1946. The draft was criticized as being "far behind even the most conservative of the unofficial drafts." 6 General MacArthur decided to present the GOJ with a draft containing principles that he believed were fundamental to a revised Constitution. SCAP's Government Section, headed by Brigadier General Whitney, had responsibility for administrative reform of Japanese governmental systems, and it prepared the draft. General MacArthur personally provided three points to be incorporated. The second of these points read:

War as a sovereign right of the nation is abolished. Japan renounces [war] as an instrumentality for settling its disputes and even for preserving its own security. It relies upon the higher ideals which are now stirring the world for its defense and protection.

No Japanese Army, Navy or Air Force will ever be authorized and no rights of belligerence will ever be conferred on any Japanese force. ${ }^{7}$

The origin of the renunciation idea is disputed. General MacArthur claimed that the idea was not his but that Prime Minister Shidehara suggested it to him. ${ }^{8}$ Shigeru Yoshida, Shidehara's Foreign Minister and later Prime Minister, stated his belief that MacArthur suggested the idea to Shidehara and Shidehara agreed. ${ }^{9}$ Professor Takayanagi, chairman of the investigation committee that investigated the formulation of the Constitution from 1957 to $1964,{ }^{10}$ originally believed in MacArthur's authorship and imposition of Article 9. Following his research, however, Takayanagi concluded that

Article 9 had its origins in Tokyo, not in Washington. The idea was first suggested by Prime Minister Shidehara, not by General MacArthur ... . No one else was present at the interview which continued for some three hours. Shidehara astonished the General with a proposal for the insertion of renunciation-of-war and disarmament clause into the new Constitution. Apparently the General hesitated at first because of the possible deleterious effects on United States foreign policy in East Asia, if the proposal were approved. The Prime Minister, however, succeeded in persuading the General that in the Atomic Age the survival of mankind should precede all national strategies, that if an atomic war should break out, America herself might be destroyed,

\footnotetext{
politicians, who were suspect in the early Meiji period, would not misuse the imperial forces. The army, in particular, misused the legislation in the 1920s and 1930s by holding the formation or continuation of a Cabinet hostage to its desires. For example, if the army was unhappy with its Depression-era budget, it could cause a Cabinet to fall by withdrawing its minister. Ultimately, General Tojo came to power in this manner. Some historians consider this control by the military over the Cabinet to be a defect of the Meiji Constitution.

4. Sato, supra note 2, at 181 .

5. Id. at 182 .

6. Political Reorientation, supra note 2, at 99.

7. O. Nishi, supra note 2, at 73 (emphasis added).

8. D. MacARThur, Reminiscences 302-03 (1964).

9. S. Yoshida, The Yoshida Memoirs: The Story of Japan in Crisis 137 (K. Yoshida trans. 1 st Am. ed. 1962).

10. See Commission, supra note 2.
} 
and that other nations must follow the same principle of renouncing war if they themselves were to survive. MacArthur was deeply impressed by this part of Shidehara's argument. Before the SCAP draft and Japanese government bill were drawn, the General and the Prime Minister agreed to insert such a clause in the new Constitution. ${ }^{11}$

SCAP's Government Section prepared its draft in less than one week and submitted it to the GOJ on February 13. Article 8 of the proposal stated:

War as a sovereign right of the nations is abolished. The threat or use of force is forever renounced as a means for settling disputes with other nations.

No army, navy, air force or other war potential will ever be authorized and no rights of belligerency will ever be conferred upon the state. ${ }^{12}$

The words "even for preserving its own security" had been deleted, but the Shidehara Cabinet was still generally shocked by the draft, particularly by the renunciation-of-war clause. ${ }^{13}$ Professor Takayanagi stated:

Before Shidehara talked with MacArthur on January 24, 1946, he had not consulted with anyone, including his Foreign Minister, Shigeru [Yoshida]. At a Cabinet meeting on February 22, reporting the results of his interview with MacArthur on the previous day, Shidehara behaved as if Article 9 were proposed by MacArthur, although he never clearly said so. If he had said the proposal was his and not MacArthur's it might have been rejected by the Cabinet. Shidehara was diplomatic enough to know this. So Cabinet members who attended the meeting, including Yoshida and Ashida, thought the proposal was made by MacArthur and not by Shidehara. After the meeting Shidehara told a number of his close friends that "Article 9 did not come from abroad" and that it was his own proposal. Neither Yoshida or Ashida was aware that the original proposal was made by Shidehara. They thought, as I did at the time, that it was imposed by the Allied Powers. These events account for the difference between Ashida's public statement at the plenary session and his private opinion in his pamphlet, and Yoshida's written memorandum sent to the Commission on the Constitution which denied that the article was Shidehara's. ${ }^{14}$

MacArthur stated in his memoirs that the renunciation clause did not prevent "any and all necessary steps for the preservation of the nation" and that, if attacked, Japan would have the right of self-defense. ${ }^{15}$ This statement, of course, conflicts with the second of MacArthur's principles that he provided to the Government Section. In 1984, Professor Nishi of Komazawa University interviewed Colonel Kades, deputy chief in 1946 of the Government Section, about the deletion of "even for preserving its own security." Kades said that he felt every country has the right of selfpreservation: "Even if they didn't have ammunition, they could fight with bamboo sticks, or something, but certainly they could defend themselves." 16

11. Takayanagi, Some Reminiscences of Japan's Commission on the Constitution, in FIRST TwENTY YEARS, supra note 2 , at 79,86 .

12. Sato, supra note 2 , at 189

13. The Japanese have gone to extraordinary lengths to determine the intent of the writers of Article 9. See, e.g., Commission, supra note 2; O. Nishi, supra note 2, at 7-14. As two Americans involved in the hearing, Charles Kades and Theodore McNelly, commented in 1987 and 1989, what the American authorities really meant is increasingly irrelevant; what is relevant is Japan's own interpretation and implementation. $I d$. at 76,87 .

14. Takayanagi, supra note 11 , at 87 .

15. D. MacArthur, supra note 8 , at 304 .

16. O. Nishi, supra note 2 , at 8-9. 
Regardless of who the author was and what the Americans believed, the GOJ explained the renunciation to the Diet as an absolute. Prime Minister Yoshida stated that he agreed with the renunciation of armed force in order to dispel fears of Japanese militarism. ${ }^{17}$ Other conservatives disagreed. ExAdmiral and Ambassador to the United States Nomura, a member of the Privy Council that received the draft for review, questioned Prime Minister Yoshida about the renumbered ninth article of the draft, specifically with reference to self-defense:

Nomura: I insist on deleting the second section of Article 9. What do we do if China, Korea or the Philippines invades?

Yoshida: Article 9 is the outcome of American apprehension about Japanese rearmament. Consequently it is difficult to revise it. Maintenance of security has to be through the Occupation Army even when attacked since we are not allowed armament; for example, even against the Soviet Union we have to rely on the United States and Britain.

Nomura: Absolute submission to the Potsdam Declaration requires the disarmament of the Japanese military but does not require a renunciation of armament forever. Even absolutely neutral countries like Switzerland have military forces and against Korea we will need armament of some sort. At the present time we are weaker than Korea. Do you intend to revise this later or will Japanese be forced to wear American uniforms? I do not insist you answer this, but this is my apprehension. ${ }^{18}$

Nomura's appeal was unheeded by the Privy Council, since the emperor had already consented to the draft.

On July 20,1946, the draft Constitution was submitted to the House of Representatives, which formed a 72-member Constitutional Amendment Committee, chaired by Ashida, to examine the draft. Two amendments to Article 9 were introduced based on suggestions by Ashida and others. First, the words "aspiring sincerely to an international peace based on justice and order" were added to the beginning of the first sentence. Second, the words "in order to accomplish the aim of the preceding paragraph" were added to the beginning of the second sentence. The explanation publicly offered at the time was that these additions would indicate in a more emphatic way Japan's sincere wish for peace by using independent judgment in expression of the provision. Only a few years later, Ashida announced that these amendments were specifically designed to allow rearmament for the purpose of selfdefense. ${ }^{19}$

Cyrus Peake, one of Government Section Chief Whitney's subordinates, advised Whitney that the Japanese revisions might someday allow Japan to maintain armed forces for self-defense. ${ }^{20}$ In 1946, Colonel Kades, Whitney's deputy who told Professor Nishi in 1984 that Japan could defend itself, told Sato, division chief of the Cabinet Legislative Bureau, that, as a result of revisions made to Article 9 in the House of Representatives, the United

17. S. Yoshida, supra note 9, at 137.

18. Commission, supra note 2, Doc. No. 46 (1960).

19. Sato, supra note 2, at 383-84.

20. Interview with Aso Shigeru, former legal staff of the National Safety Agency and the Japan Defense Agency (September 9, 1970). 
States' allies in SCAP had a "misunderstanding that Japan might have armament for purposes other than" settling disputes with any other nation"that is, for defense." 11

If MacArthur was correct in his memoirs that he never intended that Japan be unable to defend itself from attack, and if, in 1984, Kades also correctly described his 1946 belief, this idea was not well communicated either by SCAP to the GOJ or by the Yoshida Cabinet to the Japanese people. The Privy Council, the House of Representatives, and the House of Peers approved the Constitution, and the emperor granted it his sanction. It was promulgated on November 3, 1946, and went into effect on May 3, 1947. The final English version of Article 9 read:

Aspiring sincerely to international peace based on justice and order, the Japanese people forever renounce war as a sovereign right of the nation and the threat or use of force as a means of settling international disputes.

In order to accomplish the aim of the preceding paragraph, land, sea and air forces, as well as other war potential, will never be maintained. The right of belligerency of the state will not be recognized.

However, the official GOJ interpretation, which became communis opinio doctorum, and which was taught in university law schools as well as in junior and senior high schools, was that "Japan retained a right of national selfdefense in international law but, by virtue of the second paragraph, could not either wage or maintain an armed force-even for the purpose of national self-defense."22

\section{III}

\section{The Period of Flexible Interpretation}

Up until Japan regained sovereignty in April 1952, successive Japanese Cabinets maintained that armed force, even for self-defense, was not permitted. However, on July 8, 1950, shortly after the outbreak of the Korean War, General MacArthur sent a letter to Prime Minister Yoshida directing that Japan form a 75,000-man National Police Reserve ("NPR"). At this time, MacArthur began to clarify his view that he never intended that Japan could not have the means to defend itself.

21. Sato, Kempo Daikyujo no Katei (The Process Whereby Article 9 was Formulated); Commission, supra note 2, Investigative Legislative Bureau, Doc. No. 92 (1960).

22. Takayanagi, supra note 11, at 86. The San Francisco Peace Treaty of 1952, which was signed by the United States, its allies (except for the Soviet Union), and Japan, recognized Japan's inherent right of self-defense. One prominent spokesman for this opinion was Prime Minister Yoshida, who said that, if attacked, Japan would have to rely on the help of other nations. Takayanagi, at the time, personally called this communis error doctorum. Two others who disagreed with this opinion were Yoshida's political rival Ashida and Ryoichi Taoko of Kyoto University. As early as October 1946, Ashida wrote an entirely different interpretation, similar to the Kellogg-Briand Pact, allowing each nation to provide for its national self-defense. Cf. Sato, supra note 2, at 25-26. Ryoichi Taoka, who was the only Japanese member of the Hague Court of Permanent Arbitration, criticized the official interpretation as excessively rigid from the standards of international law; he also criticized Japanese intellectuals and journalists for their tendency to bend with the popular wind of the time-that is, with rightists in the immediate prewar years, and with the leftists in the immediate postwar era. Interview with Ryoichi Taoko (Nov. 13, 1970). 
The NPR was justified as necessary to maintain internal security following the transfer of SCAP forces to Korea. A special Japanese vocabulary developed to describe, for example, the NPR's tanks as "special vehicles." The former colonels and lower ranking soldiers from the defunct Imperial Japanese Army were reactivated to man the new force and were classified as reserve policemen. In his memoirs, United States Army Colonel Kowalski, who was assigned by SCAP to organize the NPR, called the NPR a mere disguise for the organization of a new Japanese army. ${ }^{23}$ Nonetheless, on March 10, 1952, over a year after the NPR was mandated, Prime Minister Yoshida stated in the Budget Committee of the House of Councillors that "to maintain war potential, even for the purpose of self-defense, would mean rearmament. This would necessitate revision of the Constitution."'24

The Japanese National Safety Forces ("NSF"), which Prime Minister Yoshida himself headed in April 1952, contained a ground and maritime element, the former being the renamed NPR. ${ }^{25}$ Against opposition party attack, Yoshida maintained that war potential forbidden by Article 9 could be differentiated from "defense potential" and that the NSF were not unconstitutional because they had no capability to wage modern warfare and thus were not an offensive threat. In August 1952, the National Safety Agency ("NSA"), which was renamed the Japan Defense Agency ("JDA") in 1954, was formally established to manage the NSF. Director General Kimura succeeded Yoshida as Safety Minister. Kimura was questioned about whether the NSF's howitzers constituted "war potential." When he denied that they did, he was asked to name an example of something that was prohibited. Kimura said that a jet airplane would constitute war potential. ${ }^{26}$ The NSA had no airplanes at that time, and Kimura had no idea then that, in the 1980s, Japan's SelfDefense Forces would fly the F-15, the most advanced fighter in the United States Air Force. In November 1952, Japan's official interpretation of war potential was provided in reply to the Japan Socialist Party's ("JSP") accusation that the NSF were unconstitutional:

Article 9, paragraph 2 of the Constitution prohibits the maintaining of a war potential whether for aggression or for self defense.

"War potential" means a force with the equipment and strength capable of conducting modern warfare ....

The Security Force and the Maritime Safety Force are not "war potential." Objectively speaking, the equipment and strength of these forces are not capable of

23. F. Kowalski, Nihon Saigumbi (The Rearmament of Japan) (1969).

24. K. Masuhara, Nihon no Boei (Japan's Defense) 57 (1961).

25. Yoshida took the position to ease public fears and in reaction to quarreling between those who wanted a unified command (favored by some former army officials and civilians) and those who lobbied for separate ground and maritime organizations (supported by the U.S. Navy officers of the Commander Naval Forces Far East staff, particularly Vice Admiral Turner Joy, the commander, and his special assistant, then Rear Admiral Arleigh Burke, later the Chief of Naval Operations, who is still today considered by Japanese naval officers to be the father of Japan's postwar navy, the Maritime Self-Defense Force). A description of postwar naval activities is contained in J. AUER, ThE Postwar Rearmament of Japanese Naval Forces, 1945-1971, at 49-89 (1973).

26. Interview with Takutaro Kimura (Dec. 17, 1970). 
effectively conducting modern warfare and hence are not to be considered "war potential" mentioned in the Constitution. ${ }^{27}$

Despite the existence of the NPR and the NSF, Yoshida insisted publicly through 1952 that "[w]e will not rearm. To rearm we must ask the consent of the people and revise the Constitution." 28 But to be eligible for large-scale U.S. military aid, Japan had to commit itself to a detailed defense plan, and the NSF were not commissioned to defend against external aggression. Thus, despite his 1952 statements, Yoshida stated in 1953 that Article 9 applied to war potential used as a means of settling international disputes and did not prohibit military power for self-defense. His thinking was then parallel to the 1950 statements of MacArthur and the 1984 statement of Kades. On September 27, 1953, Yoshida and Shigemitsu, president of the Progressive Party, concluded an agreement that stated:

In consideration of the present international situation and the spirit of national independence which is arising within our country, we will clarify the policy of increasing our self-defense strength and establish a long-range defense plan in response to the gradual reduction of U.S. armed forces stationed in our country and in proportion to our national power. Together with this measure, as a first step, we will amend the Safety Agency Law in order to reorganize the Safety Forces into the SelfDefense Forces and to add the mission of defense of our country against direct aggression to the former's mission. ${ }^{29}$

Prior to 1954, American military assistance had been incremental. It was used to form the NPR and to increase the NSF, which were composed of the NPR and the Maritime Safety Agency ("MSA"), Japan's coast guard. With the passage of the Defense Agency Establishment Law in 1954, American military assistance increased substantially. Japan began building a Ground SelfDefense Force, the third name for the NPR; a Maritime Self-Defense Force, the third name for part of the MSA; and a new Air Self-Defense Force. In June 1955, the official Cabinet policy statement on Article 9 was broadened:

The Constitution, while denouncing war, has not denounced war for self-defense ....

To check armed attack in event of such an attack from outside is self-defense itself, and is entirely different from settling international disputes. Hence, the case of military power as a means of defending the nation when the nation has been attacked by military power is not counter to the Constitution. ${ }^{30}$

The famous Cabinet policy statement of 1967 announced the three nonnuclear principles, whereby Japan pledged not to possess or manufacture nuclear weapons, and not to allow nuclear weapons to be brought into Japan. ${ }^{31}$ Less widely known is a March 12, 1959, statement of Prime Minister Kishi in the House of Councillors: "The Government intends to maintain no nuclear weapons, but speaking in terms of legal interpretation of the Constitution there is nothing to prevent the maintaining of the minimum

27. K. Masuhara, supra note 24 , at 58 .

28. Kokkai Rongi no Naka no Jieitai (The Self-Defense Forces in Diet Discussions), Keizai Orai, June 1967 , at 119 .

29. The Japan Liberal Party also agreed in principle to the communique.

30. K. Masuhara, supra note 24 , at 58 .

31. This policy statement is sometimes mistakenly referred to in English language sources as a Japanese "law" or as a "constitutional" provision. 
amount of nuclear weapons for self-defense."32 A week later, the Kishi Cabinet officially stated:

In the event that an attack is waged with guided missiles and there are no other means of defense, counter attacks on enemy bases are within the scope of self-defense. With the right of self-defense retained as an independent nation, the Constitution does not mean for the nation to sit and do nothing and await its death. ${ }^{33}$

A new U.S.-Japan Treaty of Mutual Cooperation and Security ("MST") went into effect in $1960 .{ }^{34}$ Although technically a revision of the 1952 treaty, like the Constitution, the new treaty was a completely new document. Under the earlier treaty, the United States exercised virtually unlimited rights to use U.S. bases in Japan for whatever purposes the United States desired. It was neither in form or in substance a mutual security arrangement. Under the new MST, in case of attack, the United States and Japan were to consult one another-a more explicit commitment on the parts of both countries. Further, Article V of the MST qualified U.S. base rights for use in defending Japan, while Article VI qualified U.S. base rights for use in preserving the peace and security of the Far East. Major shifts of U.S. forces into or out of Japan were also subject to prior consultation.

Despite the fact that the Japan Self-Defense Forces ("SDF") in 1989 probably had the third largest defense budget in the world, ${ }^{35}$ and despite the fact that Article 9 has never been changed, some Japanese maintained in the 1960 s and 1970s that Japan's SDF could never be effective without a change in Article 9 or a change in the MST that would give Japan reciprocal obligations outside its national territories that are similar to those that all other U.S. treaty partners have. ${ }^{36}$ Opposition parties, on the other hand, increasingly raised the issue of the limitless expansion of the SDF and tried to pin down the Japanese government as specifically as possible. In June 1965, Prime Minister Ikeda responded to a question in the Cabinet Committee of the House of Councillors: "The Self-Defense Forces are not to be determined conceptually or numerically, but the strength should be determined according

32. K. Masuhara, supra note 24 , at 59 .

33. Id.

34. Treaty of Mutual Cooperation and Security, Jan. 19, 1960, United States-Japan, 11 U.S.T. 1632, T.I.A.S. No. 4509.

35. Japan's 1988 defense budget was approximately $\$ 30$ billion using then-current exchange. The 1987 budgets of the United Kingdom, France, and the Federal Republic of Germany range in the high $\$ 20$ billion to low $\$ 30$ billion range. Japan, however, does not include in its defense budget certain items that NATO countries do include for the purpose of comparing individual countries' relative burden sharing. Using NATO criteria, Japan's 1988 budget would be approximately $\$ 40$ billion, exceeding the budgets of Great Britain, France, and the Federal Republic of Germany. Japan's budgets are also increasing at about $5 \%$ annual real growth in the $1980 \mathrm{~s}$, far faster than these NATO countries. Thus, Japan's hold on third place should solidify in the 1990s if trends continue. Japan Defense Agency, Defense of Japan 318-20 (1989).

36. In the early 1970s, a group of 100 , including several well-known academicians and politicians, called for the MST to be revised to require that the United States and Japan consult in the case of an attack on either party "in the Pacific area." This formula was similar to those used in other U.S. treaties, but was not adopted in the first and second U.S.-Japan treaties because of constitutional concerns. Such a revision also could be viewed by some Asian nations ominously as giving Japan a pretext for military activities anywhere in the Pacific. The latter was probably not the intention of at least many of the group of 100 . 
to the national situation, world affairs and the development of scientific techniques." 37 In November 1965, Prime Minister Sato was asked, "What is the constitutional limit to the expansion of self-defense power?" He responded: "The defense power is needed for self-defense of course. We would have equipment appropriate to our national power and circumstances. Thus, new conditions will always be added. Therefore it would be difficult to show where the limit is in concrete terms." 38

From 1954 to 1976, the SDF was increased in size in accordance with four Defense Build-Up Programs. In 1976, a Nationảl Defense Program Outline (Taiko) replaced the Build-up Program system and gave definition to Japan's defense missions under the MST. The Taiko called for Japan to achieve a level of standard forces listed in an annex (beppyo) in order to deal with limited and small-scale aggression and to cooperate with the United States in case of a larger attack. To ease fears that the SDF would grow too large in achieving the level in the beppyo, and because it was believed that Japan could reach that level while keeping defense expenditures below one percent of the Gross National Product ("GNP"), a 1976 Miki Cabinet decision limited defense spending to one percent of the GNP "for the time being." 39

By the early 1980s, it was obvious that a slowdown in Japan's economic growth was going to make it difficult to achieve the beppyo force level for less than one percent of the GNP. Also, in 1981, Prime Minister Suzuki and President Reagan agreed to a U.S.-Japan division of defense responsibilities in the Western Pacific. Asked what this meant for Japan in light of its Constitution, Suzuki gave a clearer statement than the Taiko by stating that Japan could "within the framework of the Constitution" protect its territory, air, and sea-lanes of communication to 1,000 miles, and that it would do so as national policy. ${ }^{40}$ Achieving this level of capability within the beppyo required high-quality forces.

Prime Minister Nakasone fully understood the implications of the 1981 communique and, in 1983, directed the preparation of a 1986 to 1990 defense plan to achieve a high-technology anti-invasion, air defense, and antisubmarine network, which would bring the SDF to the full beppyo level and achieve the level of capability necessary to meet the communique's goals. To meet Nakasone's targets, the JDA draft five-year plan required exceeding one percent of the GNP. Rebuffed in his attempt to exceed one percent for the 1986 budget, Nakasone got the five-year plan approved as government policy. In order to keep the plan on track in 1987, Nakasone finally overcame

37. A. Kyoshitsu, Nihon no Jieiryoku (Self-Defense Strength of Japan) 182 (1967).

38. Under the Peace Constitution, Peace and Security Series, Mainichi Daily News, Jan. 24, 1969.

39. The first Japanese defense budget for 1952 was $1.8 \%$ of the GNP; the total amount has grown in nominal and real terms every year since. With the phenomenal double digit growth of the GNP rate in the 1960 s, however, the budget fell to less than $1 \%$ of the GNP in 1967 and as low as $0.7 \%$ in 1971 . Some English language literature has incorrectly referred to a legal or constitutional GNP restriction on Japanese defense spending. JAPAN DefEnse AGENCY, supra note 35, at 318.

40. Question and Answer Session with Prime Minister Zenko Suzuki, The National Press Club (May 1981) (North American reporting transcript). 
opposition within his own Cabinet and moved the 1987 budget over the one percent level. ${ }^{41}$ More significantly, in January 1987, a Cabinet policy replaced the one percent limit of 1967 with a new nonquantitative limit. Rather than raising the limit to 1.1 or 1.2 percent, or "about one percent" as some wanted, the new decision said future defense programs would be limited by the international situation of the time, economic and fiscal requirements, Japan's peace-loving nature, and, of course, the spirit of the Constitution. Also, an August 1986 JDA White Paper approved by the Cabinet stated that, in the future, the beppyo of the Taiko could be modified if required by changes in the international situation, such as the technological capability of the threat facing Japan, without revision of the Taiko itself. ${ }^{42}$ Just as the virtually impossible political tasks of revising the Constitution and the MST were rendered unnecessary by flexible interpretation of both from the 1950s through the 1980s, the possibility, in the 1990s, of flexibly increasing Japan's defense capability within the Taiko has been facilitated.

IV

Court Cases and Opposition Party Views

As seen in Part III, since the early 1950s, the Japanese government, under successive conservative Governments-since 1955 those headed exclusively by the Liberal Democratic Party-has taken an increasingly pragmatic, flexible approach to Article 9. In Japan in the 1950s and 1960s, a significant percentage of Japanese citizens questioned seriously the legality of the nation's armed forces. However, by the 1970s, and increasingly in the 1980s, a strong majority of the populace came to support the SDF. Opposition to the SDF on constitutional grounds developed from three major court cases and from the major opposition political party, the Socialists.

\section{A. The Sunakawa Case}

In 1959, Japan's Supreme Court heard a case brought against a Japanese radical group that had destroyed fences and had interfered with a survey of privately owned property within Tachikawa Air Base, then used by U.S. Forces. ${ }^{43}$ In justifying their actions, the defendants claimed that the U.S.Japan treaty was unconstitutional. The Court held that self-defense was not denied to Japan as an inherent sovereign right but avoided determining the legality of war potential for self-defense or, more specifically, the legality of the SDF. ${ }^{44}$

41. From 1976 to 1985, Japanese defense plans were only Defense Agency plans. Without Cabinet approval they held little weight with the real power in Japanese bureaucracy, the Ministry of Finance. For example, from 1983 to 1985 Japanese defense budgets averaged $60 \%$ of planned funding; following government approval of the 1986 to 1990 defense plan, the 1986 to 1989 budgets have averaged full funding. C. Weinberger, Report of Allied Contributions to the Common DEFENSE (1987).

42. JaPAn Defense Agency, supra note 35, at 81 (1986).

43. Sakata v. Japan (The Sunakawa Case), 13 Keishū 3225 (Sup. Ct., G.B., Dec. 16, 1959).

44. Id. 


\section{B. The Naganuma Case}

The Japan Defense Agency desired to construct a missile base in Hokkaido as part of the 1967-1971 Defense Build-Up Program. Local residents protested and brought legal action against the Ministry of Agriculture and Forestry. In 1973 the Sapporo District Court held that the SDF were military units and thus were unconstitutional. ${ }^{45}$ The court directed the Ministry to retract its permit allowing the JDA to use the forestry preserve. In doing so, the court affirmed Japan's right of self-defense as an independent state, but stated that this right should be achieved through diplomacy, police action, revolution by the masses, confiscation of the property of citizens from aggressor nations, deportations, and other non-military measures. ${ }^{46}$

In 1976, the Sapporo High Court reversed the district court decision. ${ }^{47}$ The high court held that Paragraph 1 of Article 9 prohibits wars of aggression. It further held, however, that the second paragraph contains dual positive and negative doctrines, both of which are logical even though they are contradictory. The court also stated that the law establishing the SDF does not indicate an aggressive tone and thus the court was unable to draw conclusions about the constitutionality of the SDF. In 1982 the Supreme Court upheld the high court's decision that the case was not constitutionallybased but instead was merely a political issue; thus the residents did not have a right to sue. ${ }^{48}$

\section{The Hyakuri Base Case}

The third major case opposing the SDF on constitutional grounds concerned the sale of property desired by the Government for use as an air base. A farmer first sold his property to a private buyer in opposition to the construction of the air base. When the buyer failed to pay, the seller changed his decision and together with the government sued for his proprietary right. As in Naganuma, the court considered the constitutional issue when the buyer claimed that the existence of the SDF violated public peace and order.

In 1977, the Mito District Court went further than the Sapporo High Court by stating that self-defense for the purpose of preventing foreign attack was not constitutionally prohibited, thus making self-defense a legal, rather than a political, issue:

In effect, the use of the right of self-defense for the purpose of preventing and eliminating armed foreign attacks and for organizing and equipping effective and appropriate defense dispositions in advance does not violate Article 9 of the Constitution. ${ }^{49}$

45. Ministry of Agriculture and Forestry v. Ito, 36 Minshū 1679 (Sup. Ct., lst P.B., Sept. 9, 1982) (aff'g 27 Gyōhan 1175 (Sapporo H. Ct., Aug. 5, 1976) and rev'g 712 Hanrei Jihō 24 (Sapporo Dist. Ct., Sept. 7, 1973)).

46. O. NisHI, supra note 2 , at 20-22.

47. 27 Gyōhan 1175.

48. 36 Minshū 1679. See O. Nishi, supra note 2, at 22-23.

49. 43 Minshū 385 (Sup. Ct., 3d P.B., June 20, 1989). See O. Nishi, supra note 2, at 24. 
The decision did treat the question of the legality of the SDF, however, as a political matter:

The decision of whether the SDF exceed the necessary limits termed "war potential" under Paragraph 2, Article 9 is, in principle, not under the jurisdiction of the courts of justice unless it is clearly unconstitutional and invalid. This decision is primarily entrusted to the Diet, the body that legislated the two defense laws and is therefore ultimately responsible to the Japanese public. However, it is almost impossible to claim that the SDF are clearly a "war potential," or an organization of men and resources capable of conducting aggressive war. Based on this realization, the dispute of whether the former Defense Agency Establishment Law and the former SDF Law are unconstitutional should be left a political question and should not be decided by the courts. Thus the aforementioned two laws cannot be declared unconstitutional and invalid. ${ }^{50}$

Subsequently, the Tokyo High Court in 1981 and the Supreme Court in June 1989 also avoided the constitutional question and treated the matter as a purely political dispute.

\section{The Japan Socialist Party's Position}

The Japan Socialist Party has attacked the constitutionality of self-defense forces since the formation of the NPR and the NSF in the early 1950s. The official Party view remains that the SDF violate the Constitution. This view, however, has not received popular support. According to polls conducted by the Prime Minister's office, approval for the SDF reached close to 90 percent in the $1980 \mathrm{~s},{ }^{51}$ causing some individual Party leaders, including former Chairman Ishibashi, to espouse the view that the SDF are unconstitutional but legal since the SDF law and the Defense Agency Establishment Law were legally passed by the Diet. Ishibashi "withdrew" his opinion after some Party members objected, ${ }^{52}$ and the position of the Japan Socialist Party at present calls for the realization of an international system based on peace and cooperation as well as nonalliance, neutrality, and nonarmament. The policy states that if the JSP takes power it will disband the SDF in three steps. First, it will obtain the voluntary cooperation of SDF members through education in order to ensure democratic privileges. Next, it will reduce the size of the SDF. Finally, it will disband the SDF and reassign a portion of the members to form the Peaceful Environment Establishment Force. ${ }^{53}$

\section{E. Positions of other Japanese Political Parties}

The Democratic Socialist and Clean Government (Komeito) parties do not deny Japan's right to maintain self-defense with armed force, ${ }^{54}$ and the Japan Communist Party, while maintaining that the SDF are "armed forces subordinate to the U.S. and oppressing the Japanese citizenry in violation of

50. 43 Minshū 385; see O. Nishi, supra note 2, at 24.

51. Japan Defense Acency, supra note 35 , at 199.

52. O. NisHI, supra note 2 , at 13 .

53. Id. at 30-31.

54. Id. at 34 . 
the Constitution," 55 also ridicules unarmed neutrality. With respect to the Constitution the Communist Party states that:

In progressing towards a socialist Japan it is natural to strive for a truly democratic Constitution suitable for an independent nation approved by the will of the citizens. The necessary defense measures will be in conformity with the domestic and international affairs at the time of the new Constitution and will be written under the collective will of the citizens. ${ }^{56}$

\section{An American's Analysis of Article 9}

The fact is well-known that Japan spends only a fraction over one percent of its GNP for defense, forty years after the Constitution was promulgated. It is less appreciated, however, that the SDF are increasingly becoming a meaningful element of the U.S.-Japan Treaty of Mutual Cooperation and Security, which is the United States' most important security arrangement anywhere in the Pacific and which already rivals in importance the United States' ties with the North Atlantic Treaty Organization.

As noted in Part III, Japan's defense budget is now the third largest in the world and the largest among nonnuclear powers. The Maritime Self-Defense Force has more destroyer-type vessels ${ }^{57}$ than the Royal Navy and more than twice as many as the United States Seventh Fleet, the division responsible for the Western Pacific and Indian Oceans. The Air Self-Defense Force has more than 300 fighter aircraft, more than the United States Air Force deploys in Japan, Korea, and the Philippines combined, and approximately as many as are used to defend the continental United States. ${ }^{58}$

By the early 1990 s, Japan will have 100 sophisticated P3C antisubmarine aircraft, ${ }^{59}$ four times as many as the Seventh Fleet has today. In addition, it will have $200 \mathrm{~F}-15 \mathrm{~s},{ }^{60}$ the most modern fighter aircraft in the U.S. inventory, a large number of sophisticated Patriot air defense missiles, and the advanced Aegis sea-based air defense system. Later in the decade, Japan is likely to acquire long-range airborne early-warning aircraft ("AWACS"), tanker aircraft, and long-range/broad-area Over-the-Horizon Radar. ${ }^{61}$ As a result, even though defense spending will remain very close to one percent of the GNP, Japan will possess an extremely sophisticated air defense and antisubmarine warfare capability that will make it very difficult for Soviet ships and aircraft to enter the Sea of Japan or the Pacific Ocean without being detected by the Japan Self-Defense Forces. Complicating Soviet planning in such a manner is the essence of deterrence, which in the nuclear age is the

\footnotetext{
55. Id.

56. Id. at 35 .

57. JaPAn Defense Agency, supra note 35 , at 301.

58. C. WEINBERGER, supra note 41 .

59. Id.

60. $I d$.

61. Id.
} 
only possible "victory" in any international conflict serious enough to trigger military action.

Despite the Japanese public's early opposition to the armed forces, and despite the fact that any attempt to change Article 9 would still be very unpopular both in Japan and elsewhere in Asia, support for the SDF has grown steadily since the early $1950 \mathrm{~s}$. As noted, today a very respectable 90 percent of the Japanese public supports the existence of the SDF and acknowledges that the mission of self-defense is more important than civil disaster relief, a role the public held to be more important in the SDF's formative years.

Do the Japanese actions since 1947 mean that the Constitution has been disregarded and that Japan is pursuing a dangerous path towards militarism? This American analysis argues in the negative to both questions. The government of Japan was ordered to form the NPR in 1950, and, unless Japan had agreed to form the NSF in 1952, the Occupation of Japan would have continued. At least since 1970 Japan has had the right to terminate the U.S.Japan Treaty of Mutual Cooperation and Security with one year's notice, but the growth of Soviet military power in the Soviet Far East made such Japanese action unrealistic.

\section{VI}

\section{Conclusion}

After over forty years under the Constitution, Japan has sincerely endeavored to live within the spirit of Article 9 and has been extremely sensitive to domestic and Asian public opinion in building a meaningful but limited defense capability, clearly complementary to rather than autonomously separate from U.S. military power. Moreover, this Japanese defense capability has little if any utility other than for civil disaster relief or for defense outside the confines of the U.S.-Japan Treaty.

Owing to its seriously vulnerable, strategic location 200 to 500 miles across the Sea of Japan from the Soviet Union, Japan (whose economy is now larger than the USSR's and which will continue to grow more quickly) cannot, with its limited military power, "go neutral." What Japan can do is tilt towards the Soviet Union or towards the United States and hope that deterrence will continue. Given that choice and the history of uneasy Russo/Soviet-Japanese relations, Japan is, not surprisingly, tilting toward the United States.

Japan's survival in case of a major U.S.-Soviet military confrontation is extremely doubtful, given the value of Japan's economy and its proximity to Soviet territory. Japan's small size and vulnerable location seriously limit its war-fighting capability now and in the future. However, the Soviet Union must first concentrate its military efforts on Eastern Europe and on its long border with China before contemplating a potential third front in the Pacific. Consequently, the strategic importance of Japan's location, Tokyo's ability to finance a high-technology air defense and antisubmarine barrier 500 miles 
either side of Vladivostok, and a nuclear blackmail shield provided by the United States provide Japan with a very strong war-deterring capability. A strong deterrent obviously benefits Japan and, given the increasing economic importance of the Pacific Basin, the United States and many other countries as well.

As long as this complementary relationship of U.S. and Japanese security forces endures, public opinion in Japanese and other non-Communist Asian nations is likely to continue to support Japanese defense efforts, which are and will remain compatible with a flexible interpretation of Article 9 as written forty years ago. A withdrawal of U.S. forces from the Pacific would create a vacuum that the Soviets, the Chinese or, some would say, the Japanese would fill. Thus, Japan's defense efforts would be for naught or would take on a wholly different character, far from defense against aggression as required by Article 9.

It is difficult to understand calls in the United States Congress, which have occurred as recently as May 1987, for Japan to increase its defense spending to three percent of the GNP. A Japanese defense budget of three percent of the GNP could easily finance offensive and strategic weapons that neither the Japanese public nor Japan's Asian neighbors desire. Japanese forces with such capability, regardless of their name, would not be consistent with even a flexible interpretation of the Constitution.

The United States and other nations regard the present level of Japanese defense and foreign aid spending (1.3 percent of the GNP) as insufficient. There is much that Japan can do in the context of comprehensive security, within a reasonable and flexible interpretation of Article 9, to increase its security contribution in a manner acceptable to the Japanese public and to Japan's allies and trading partners. Given the parameters of Soviet military capability in the Pacific, Japan's increasingly meaningful defense efforts can be expedited without becoming excessive, and the SDF's abilities to carry out their assigned roles can be further enhanced, as described above. Supplies of ammunition, in particular, can be strengthened, giving the SDF increased credibility.

As long as the character of the SDF and their relationship to U.S. forces remains as called for in U.S.-Japan security arrangements, even such tasks as the deployment of the SDF to the Persian Gulf for minesweeping, described in 1987 as constitutional by Prime Minister Nakasone, need not cause alarm. Such activities could demonstrate the importance of the SDF to free navigation. With amendment to the SDF law, not to the Constitution, the SDF could participate in peacekeeping activities. For example, the Maritime Self-Defense Force could protect commercial reprocessed plutonium shipments from Europe against terrorist attacks.

A strategically targeted, properly managed, united Japanese foreign aid program could have immense national security relevance in the 1990 s and twenty-first century, equal to or greater than the Marshall Plan in the 1940s and 1950s. Increased Japanese willingness to provide the world's finest dual- 
use technology-a technology enormously relevant to present and future U.S. military capability - would be a very significant step. In addition, Japan could more effectively deny this technology to the Soviet Union, whose desire for Toshiba milling machines shows a recognition of the importance of Japanese technology. Similarly, Japan is already spending in excess of 2.5 billion dollars ${ }^{62}$ annually to maintain U.S. forces in Japan. Although this sum is the most generous support the United States enjoys anywhere, increased assumption of these costs is also a potentially useful way for Japan to do more.

As a strong American supporter of effective Japanese defensive capability, and as a believer that revision of Article 9 is a decision that the Japanese people must make for themselves, this author hopes that the United States Congress will more carefully consider U.S. and Japanese security interests and will exercise prudence and sensitivity when it tries to link trade and defense issues in the future.

62. Information supplied by Embassy of Japan, Washington, D.C., July 1989. 
